Kebahagiaan Pemimpin Perempuan Dalam Menjalani......

\title{
KEBAHAGIAAN PEMIMPIN PEREMPUAN DALAM MENJALANI PERAN GANDA PERSPEKTIF PSIKOLOGI
}

\author{
Titin Nurhidayati ${ }^{1}$ \\ IAI Al-Falah As-sunniyyah Kencong Jember \\ titinnurhidayati77@gmail.com
}

\begin{abstract}
Positive psychology is the flow of modern psychology that focuses its studies on the positive aspects of humans and leads people not just to live, but to live happily. One of the benefits of happiness itself is reflected through the success of women in achieving careers as leaders in the workplace and still being able to carry out their roles as wives and mothers well. The balance of their roles shows that women have the ability to be leaders in the workplace, without leaving their roles as wives and mothers in the family.
\end{abstract}

Keywords: Happiness, Women Leaders, Multiple Roles

Abstrak

Psikologi positif merupakan aliran psikologi modern yang memfokuskan kajiannya pada sisi-sisi positif manusia dan mengantarkan manusia bukan hanya untuk sekedar hidup, tetapi hidup bahagia. Manfaat dari kebahagiaan itu sendiri salah satunya tercermin melalui keberhasilan perempuan dalam mencapai karir sebagai pemimpin di tempat kerja dan tetap mampu menjalankan perannya sebagai istri dan ibu dengan baik. Keseimbangan peran yang mereka jalankan menunjukkan bahwa perempuan memiliki kemampuan untuk menjadi pemimpin di tempat kerja, tanpa meninggalkan perannya sebagai istri dan ibu di keluarga.

Kata Kunci: Kebahagiaan, Pemimpin Perempuan, Peran Ganda

\section{Pendahuluan}

Manusia sebagai pemegang peranan penting di dunia memiliki sisi-sisi yang beragam untuk dipelajari. Salah satu ilmu yang memiliki fokus pada manusia adalah psikologi, yaitu mempelajari manusia dilihat dari aspek perilakunya. Teori-teori psikologi yang dipelopori oleh para ilmuwan seperti Sigmund Freud, Carl Gustav Jung, dan Burrhus Frederic Skinner ikut memberikan sumbangan besar dalam perkembangan keilmuan psikologi di seluruh dunia.

\footnotetext{
${ }^{1}$ Dosen Tetap Institut Agama Islam Al-Falah As-Sunniyyah Kencong Jember. 
Titin Nur Hidayati

Selama setengah abad terakhir teori-teori tersebut juga turut mendasari fokus psikologi pada topik bahasan mengenai penyakit mental atau mental illness. Berbagai penelitian mengenai gangguan mental yang ada saat ini membuktikan bahwa psikologi telah berhasil menjelaskan dan memahami dengan cukup akurat konsep-konsep yang kabur, bahkan dapat mengatasi dan mengetahui cara-cara meredakan gangguan-gangguan seperti depresi, schizofrenia, dan alkoholisme dengan cukup tepat. ${ }^{2}$

Pada perkembangan selanjutnya manusia mulai merasakan bahwa usaha untuk menangani dan membebaskan diri dari gangguan mental saja belum cukup, manusia memerlukan cara agar mereka dapat merasakan kebahagiaan dalam hidupnya, bukan sekedar mengurangi kesedihan, depresi atau gangguan mental lainnya. Keinginan yang besar dalam pencarian kebahagiaan dinyatakan dengan jelas, salah satunya oleh bangsa Amerika yang memasukkan unsur kebahagiaan dalam Deklarasi Kemerdekaannya "life, liberty, and the pursuit of happiness ".Melalui deklarasi tersebut setiap warga negara Amerika memiliki hak untuk mencari dan merasakan kebahagiaan dalam hidup. ${ }^{3}$

Kebahagiaan juga akan memberikan dampak positif yang besar dalam berbagai aspek kehidupan yang akan mengarah pada hidup yang baik dan menunjukkan produktivitas yang lebih besar. Kebahagiaan akan mengarahkan manusia pada kesehatan, performansi kerja, hubungan sosial, dan perilaku yang lebih baik. ${ }^{4}$

\footnotetext{
2 Seligman, Martin E.P. Authentic Happiness: Menciptakan Kebahagiaan dengan Psikologi Positif. (Bandung: Mizan, 2002), xiii.

${ }^{3}$ Ibid, xiv

${ }^{4}$ Diener, E. \& Kesebir, P. In Pursuit of Happiness: Empirical Answers to Philosophical
} Questions. Volume 3 No. 2, 2008, 121.

36 | Falasifa, Vol. 11 Nomor 1 Maret 2020 
Kebahagiaan Pemimpin Perempuan Dalam Menjalani.....

Kebahagiaan yang dirasakan oleh setiap orang bersifat subyektif dan tidak akan sama karena mereka memiliki perbedaan faktor yang mendasarinya. Misalnya ada orang yang merasakan kebahagiaan karena rasa puasnya terhadap kemampuan yang dimiliki untuk menyelesaikan tugas-tugas dalam pekerjaan maupun keberhasilannya dalam membina rumah tangga. Ada juga orang yang tidak memiliki banyak materi tetapi mereka merasakan kebahagiaan hidup dan puas dengan apa yang telah mereka dapatkan, begitu pula sebaliknya ada orang yang berlimpah materi tetapi mereka justru merasakan hidupnya hampa dan tidak bahagia. Hal tersebut menunjukkan bahwa sebenarnya kebahagiaan juga bergantung pada penilaian, cara pandang, dan kemampuan seseorang dalam menyikapi segala keadaan dalam hidupnya secara positif.

Seseorang yang berhasil menemukan kebahagiaan dalam hidupnya tentu akan lebih kuat dalam mengatasi goncangan kehidupan jika dibandingkan dengan orang lain yang tidak dapat memaknai hidup secara positif. Hal tersebut didukung oleh penelitian yang dilakukan Lisa Aspinwall, seorang profesor di Universitas Utah. Aspinwall berhasil mengumpulkan banyak bukti kuat yang menyatakan bahwa dalam mengambil keputusan penting pada kehidupan nyata, mereka yang bahagia bisa lebih pintar daripada mereka yang tidak bahagia. $^{5}$

Berdasarkan beberapa penelitian di atas, maka dapat diketahui bahwa kebahagiaan membawa pengaruh besar dalam proses pengambilan keputusan dalam hidup. Pengambilan keputusan merupakan proses penting yang dilakukan oleh setiap orang untuk menyelesaikan suatu permasalahan dan mencapai tujuan tertentu dalam hidup.

Falasifa, Vol. 11 Nomor 1 Maret 2020| 37 
Titin Nur Hidayati

Pengambilan keputusan juga mutlak dilakukan oleh seorang pemimpin untuk menentukan kemajuan sebuah organisasi. Keputusan yang ditentukan oleh pemimpin berkaitan erat dengan strategi kerja yang akan dijalankan bersama dalam organisasi, karena secara operasional seorang pemimpin memiliki kewajiban pokok untuk berusaha mencapai tujuan dan cita-cita bersama serta memperhatikan hal-hal yang mendukung usaha untuk mencapai tujuan dan cita- cita tersebut. ${ }^{6}$

Peran pemimpin sebagai tonggak penting suatu organisasi seperti penjelasan di atas. dapat dijalankan oleh pria maupun perempuan, karena pada dasarnya pria dan perempuan sama-sama memiliki kelebihan dan potensi untuk memimpin di berbagai bidang pekerjaan. Akan tetapi, kenyataan yang sering dijumpai di lapangan menunjukkan bahwa jabatan sebagai pimpinan dalam suatu organisasi mayoritas dijalankan oleh pria. Sebagian besar perempuan belum berhasil mencapai posisi tersebut karena dilatarbelakangi oleh berbagai faktor, baik faktor eksternal maupun internal yang berasal dari dalam diri para perempuan.

\section{Kebahagiaan dalam Tinjauan Psikologi}

Munculnya psikologi positif sebagai kajian modern dalam dunia psikologi diharapkan dapat mendorong manusia untuk menyadari sifat-sifat positif yang dimilikinya, sehingga mereka dapat mencapai sebuah hidup yang lebih bahagia dan berkualitas.

Kebahagiaan merupakan evaluasi yang dilakukan seseorang terhadap hidupnya, mencakup segi kognitif dan afeksi. Evaluasi kognitif sebagai komponen kebahagiaan

\footnotetext{
${ }^{5}$ Seligman, Martin E.P. Authentic Happiness, 48.

${ }^{6}$ Anorogo, P. \& Widiyanti, N. Psikologi dalam Perusahaan. (Jakarta: PT. Rineka Cipta, 1993), 118.

38 | Falasifa, Vol. 11 Nomor 1 Maret 2020
} 
Kebahagiaan Pemimpin Perempuan Dalam Menjalani.....

seseorang diarahkan pada penilaian kepuasan individu dalam berbagai aspek kehidupan, seperti pekerjaan, keluarga, dan pernikahan. Sedangkan evaluasi afektif merupakan evaluasi mengenai seberapa sering seseorang mengalami emosi positif dan negatif. ${ }^{7}$

Kebahagiaan memberikan berbagai dampak positif dalam segala aspek kehidupan dan akan mengarahkan pada hidup yang lebih baik, misalnya memberikan kita kesempatan untuk menciptakan hubungan yang lebih baik, menunjukkan produktivitas yang lebih besar, memiliki umur yang lebih panjang, kesehatan yang lebih baik, kreativitas yang lebih tinggi, dan kemampuan pemecahan masalah dan membuat keputusan mengenai rencana hidup dengan lebih baik. ${ }^{8}$ Kebahagiaan terasa tidak hanya ketika seseorang mendapatkan apa yang diinginkan, tetapi juga ketika menginginkan apa yang telah didapatkan.

Sejalan dengan ungkapan di atas, pemaknaan terhadap kebahagiaan oleh sebagian besar orang di masa modern saat ini memiliki perbedaan dengan orang-orang pada era sebelumnya, seperti dijelaskan dalam kutipan berikut: "bumans in this day and age think of happiness more as feeling good than being good". 10

Sebagian besar orang saat ini memaknai kebahagiaan sebagai perasaan nyaman dalam suatu kondisi yang baik, misalnya seorang pemimpin merasa bahagia karena rasa cinta, semangat, dan kenyamanan mereka dalam menjalankan tugas dan tanggung jawabnya sebagai pemimpin, serta mampu memberikan hal yang bermanfaat melalui aktivitasnya tersebut, bukan semata-mata karena jabatan yang dimilikinya.

${ }^{7}$ Astuti, D. T. Hubungan Antara Tingkat Kebahagiaan Autentik (Authentic Happiness) dengan Tingkat Perilaku Inovasi Pada Wirausahawan Distro Di Surabaya, Sidoarjo, dan Malang. (Surabaya: Universitas Airlangga, 2007$), 29$. 2009, 2.

${ }^{8}$ Oriza, I. D. I. Hubungan antara Kekuatan Karakter dan Kebahagiaan Pada Suku Bugis. C-S Bugis Jurnal.

${ }_{9}$ Larsen, J. T. \& McKibban, A. R. (2008). Is Happiness Having What You Want, Wanting What You Have, or Falasifa, Vol. 11 Nomor 1 Maret 2020| 39 
Titin Nur Hidayati

Perasaan bahagia bergantung lebih pada bagaimana orang memperlakukan hidup daripada hidup yang memperlakukan mereka. Kebahagiaan itu sendiri bergantung pada empat unsur, yaitu material, intelektual, emosional, dan spiritual. Keempat unsur tersebut harus berjalan dengan seimbang apabila seseorang ingin mendapatkan kebahagiaan. ${ }^{11}$

Penilaian mengenai kebahagiaan yang dirasakan oleh setiap individu merupakan hal terpenting yang perlu diperhatikan dalam kajian tentang kebahagiaan. Beberapa tokoh yang mengkaji tentang kebahagiaan telah sepakat bahwa kebahagiaan bersifat subyektif dan masingmasing individu merupakan penilai terbaik mengenai kebahagiaan yang dirasakannya. Hal tersebut sesuai dengan pernyataan berikut "this conceptualization emphasizes the subjective nature of happiness and holds individual human being to be the single best judges of their own happiness". ${ }^{2}$

Kebahagiaan dalam tinjauan psikologi diartikan sebagai hasil penilaian diri terhadap kepuasan hidup yang ditandai dengan munculnya emosi dan aktivitas positif di sebagian besar waktu serta keseimbangan dalam menjalankan hidup, yang ditentukan oleh empat aspek yaitu material, intelektual, emosional, dan spiritual. Setiap orang merupakan penilai utama mengenai kebahagiaan yang mereka rasakan, karena mereka adalah pihak yang terlibat langsung dengan proses pencapaian kebahagiaan dalam hidupnya, sehingga ketika mereka telah merasakan kebahagiaan tersebut maka merekalah yang dapat menilai dan mendeskripsikannya secara tepat.

Both?. Volume. 19, No. 4, 2008, 371.

${ }^{10}$ Diener, E. \& Kesebir, P.In Pursuit of Happiness, 118.

${ }^{11}$ Khavari, K.A. The Art of Happiness: Mencipta Kebahagiaan dalam Setiap Keadaan. (Jakarta: PT. Serambi Ilmu Semesta, 2006), 24.

${ }^{12}$ Diener, E. \& Kesebir, P. In Pursuit of Happiness. 118.

40 | Falasifa, Vol. 11 Nomor 1 Maret 2020 
Kebahagiaan Pemimpin Perempuan Dalam Menjalani.....

\section{Faktor-faktor yang Mempengaruhi Kebahagiaan Ditinjau dari Perspektif Psikologi}

Berbagai faktor yang memiliki pengaruh besar dalam kebahagiaan seseorang, diantaranya kemampuan dalam berpikir positif, kepuasan kerja, kepuasan dalam pernikahan, kehidupan sosial, agama, serta kekuatan dan kebajikan.

Kepuasan kerja merupakan salah satu faktor pembentuk kebahagiaan dalam kehidupan seseorang. Perasaan puas pada pekerjaan sendiri dan perasaan berfaedah berkorelasi erat dengan kebahagiaan. Pekerjaan menjadi bukan hanya alat untuk mendapatkan uang, tetapi juga isyarat bahwa seseorang dihargai dan dibutuhkan oleh orang lain, dan juga meyakinkan bahwa seseorang melakukan hal yang bermanfaat. Hasil kerja yang memuaskan, baik yang diberi upah atau tidak, mendorong seseorang untuk memandang ke depan dan berpartisipasi menciptakan kebaikan bersama. ${ }^{13}$

Perkawinan juga memiliki hubungan yang sangat erat dengan kebahagiaan seseorang, tidak seperti uang yang hanya berpengaruh kecil pada kebahagiaan. Berdasarkan berbagai survei, salah satunya yang diadakan oleh Pusat Riset Opini Nasional Amerika Serikat, menyatakan bahwa kebahagiaan orang yang menikah mempengaruhi panjang usia dan besar penghasilan, dan hal ini berlaku bagi laki-laki dan perempuan. Namun bagi mereka yang menjalani perkawinan tidak harmonis memiliki tingkat kebahagiaan yang lebih rendah daripada mereka yang tidak menikah atau bercerai. ${ }^{14}$

Mengenai kehidupan sosial, orang yang sangat bahagia jauh berbeda dengan orang rata-rata dan orang yang tidak bahagia, yaitu mereka menjalani kehidupan sosial yang kaya dan memuaskan. Orang-orang yang sangat bahagia paling sedikit menghabiskan waktu

\footnotetext{
${ }^{13}$ Khavari, K. A. The Art of Happiness. 134.
}

Falasifa, Vol. 11 Nomor 1 Maret 2020| 41 
Titin Nur Hidayati

sendirian dan kebanyakan dari mereka bersosialisasi. Kemampuan bersosialisasi yang meningkat itulah mungkin yang sebenarnya menjadi penyebab dari temuan positif tentang perkawinan, dengan fakta bahwa orang yang lebih bersosialisasi (yang juga lebih bahagia) lebih mungkin untuk menikah. Oleh karena itu, besar pula kemungkinannya bahwa kehidupan sosial (dan perkawinan) yang kaya akan membuat orang bahagia. ${ }^{15}$

Selain kemampuan berpikir positif, kepuasan kerja dan pernikahan, agama juga merupakan unsur penting untuk meraih kebahagiaan hidup. Agama akan mengisi manusia dengan harapan akan masa depan dan menciptakan makna dalam hidup. Hubungan antara harapan akan masa depan dan keyakinan beragama mungkin merupakan landasan mengapa keimanan begitu efektif melawan keputusasaan dan meningkatkan kebahagiaan. ${ }^{16}$

Sejalan dengan faktor-faktor pembentuk kebahagiaan di atas, apabila seseorang ingin meningkatkan kebahagiaan hidupnya, maka menjalankan kemauan lebih penting dibanding menyusun ulang penyangga eksternal. Hal tersebut dilakukan dengan cara membangun kekuatan dan kebajikan serta menggunakannya dalam kehidupan sehari-hari berkaitan dengan masalah membuat pilihan. ${ }^{17}$

Melalui proses penelusuran terhadap tulisan-tulisan fundamental dari semua agama utama dan tradisi filsafat yang diterima secara universal, maka ditemukan enam buah kebajikan, yaitu kearifan dan pengetahuan, keberanian, cinta dan kemanusiaan, keadilan,

\footnotetext{
${ }^{14}$ Seligman, Martin E.P. (2005). Authentic Happiness. 71

${ }^{15}$ Ibid. 72.

${ }^{16}$ Ibid, 78.

${ }^{17}$ Ibid, 176.
}

42 | Falasifa, Vol. 11 Nomor 1 Maret 2020 
Kebahagiaan Pemimpin Perempuan Dalam Menjalani.....

kesederhanaan, spiritualitas dan transendensi. ${ }^{18}$

Enam buah kebajikan yang dikemukakan di atas selanjutnya mendorong dua puluh empat kekuatan pada diri seseorang dan telah diakui oleh banyak budaya. Kekuatan adalah ciri khas, sebuah karakter psikologis yang dapat dilihat pada situasi apapun dan muncul sepanjang waktu dan dinilai karena dirinya sendiri. ${ }^{19}$

Berikut ini adalah penjabaran dan penjelasan keenam jenis kebajikan beserta dua puluh empat kekuatan yang ada pada diri seseorang. ${ }^{20}$

\section{a. Kearifan dan Pengetahuan}

Kelompok pertama kebajikan adalah kearifan dan kata turunannya yaitu pengetahuan, mulai dari yang paling mendasar (keingintahuan) sampai pada yang paling matang (perspektif). Kearifan dan pengetahuan terdiri dari:

1) Keingintahuan/Ketertarikan terhadap Dunia

Keingintahuan terhadap dunia mencakup keterbukaan seseorang terhadap pengalaman dan fleksibilitas terhadap sesuatu yang tidak sesuai dengan konsepsi awalnya. Seseorang yang memiliki rasa ingin tahu tinggi tidak hanya sekedar toleran terhadap ambiguitas, tetapi mereka menyukainya dan tertarik untuk membedahnya. Keingintahuan dapat bersifat spesifik maupun global. Rasa ingin tahu secara aktif mengikutsertakan hal baru, sehingga penyerapan informasi secara pasif tidak akan menampilkan kekuatan khas ini.

2) Kecintaan untuk Belajar

Kecintaan untuk belajar ditunjukkan dengan kesukaan seseorang untuk

\footnotetext{
${ }^{18}$ Ibid, 171.

${ }^{19}$ Ibid, 177.
}

Falasifa, Vol. 11 Nomor 1 Maret 2020| 43 
Titin Nur Hidayati

mempelajari hal-hal baru dimanapun ia berada. Kecintaan belajar juga ditandai dengan kesukaan seseorang untuk mempelajari bidang tertentu walaupun tidak ada insentif eksternal apapun untuk melakukannya. Kecintaan untuk belajar akan mencerminkan kekuatan khas apabila suatu pengetahuan dipelajari demi pengetahuan itu sendiri.

3) Pertimbangan/Pemikiran Kritis/Keterbukaan Pikiran

Pertimbangan atau berpikir kritis dilakukan dengan menjalankan penyaringan informasi dengan obyektif dan rasional demi kebaikan diri sendiri dan orang lain. Orang yang memiliki keterbukaan pikiran akan sanggup mengubah pikiran, tidak tergesa-gesa dalam mengambil suatu keputusan dan selalu bersandar pada bukti-bukti yang kuat dalam menyikapi sesuatu.

4) Kecerdikan/Orisinalitas/Inteligensia Praktis/Kecerdasan Sehari-hari

Kekuatan kecerdikan/orisinalitas ditunjukkan seseorang melalui kepandaian menemukan perilaku yang baru tetapi tepat untuk meraih suatu tujuan yang diinginkan dan jarang merasa puas dalam mengerjakan sesuatu melalui cara konvensional. Kategori ini juga meliputi kreativitas seperti yang dimaksudkan oleh orang pada umumnya, tetapi tidak dibatasi oleh aktivitas kesenian murni. Kekuatan ini juga disebut inteligensia praktis, pikiran sehat (common sense) atau kecerdasan sehari-hari.

5) Kecerdasan Sosial/Kecerdasan Pribadi/Kecerdasan Emosional

Kecerdasan sosial dan pribadi merupakan pengetahuan mengenai diri sendiri dan orang lain. Kecerdasan sosial adalah kemampuan melihat perbedaan di antara orang lain, terutama berkaitan dengan suasana hati, tempramen, motivasi, dan niat mereka, yang 
Kebahagiaan Pemimpin Perempuan Dalam Menjalani.....

kemudian bersikap berdasarkan perbedaan tersebut. Kekuatan ini terwujud dalam bentuk tindakan sosial yang terampil, bukan sekedar sikap introspektif, berpikir dengan memperhatikan aspek psikologi, atau merenung. Aspek lain dari kekuatan ini adalah kemampuan untuk menempatkan diri secara tepat dan kemampuan menempatkan diri dalam kondisi yang memaksimalkan keahlian dan minat diri.

6) Perspektif

Perspektif merupakan kekuatan paling matang pada kategori ini dan paling mendekati kearifan itu sendiri. Hal ini ditunjukkan dengan adanya cara pandang seseorang terhadap dunia yang terasa masuk akal bagi orang lain dan dirinya sendiri. Orang yang arif merupakan pakar dalam hal-hal yang penting dalam hidup, sehingga orang lain akan menimba pengalaman darinya untuk membantu menyelesaikan persoalan mereka dan mendapatkan perspektif mereka sendiri.

\section{b. Keberanian}

Kekuatan-kekuatan yang menyusun kebaikan adalah tekad yang dijalankan dengan waspada untuk menuju hasil akhir yang bernilai tetapi belum pasti. Untuk masuk dalam kualifikasi keberanian, tindakan tersebut harus dijalankan dengan menghadapi penderitaan yang hebat. Kepahlawanan, ketekunan, dan integritas merupakan tiga rute yang umum diterima di berbagai tempat untuk menuju jenis kebajikan ini.

1) Kepahlawanan dan Ketegaran

Kekuatan ini merujuk pada pendirian intelektual atau emosional yang tidak populer, sulit, dan berbahaya. Seseorang yang tegar akan mampu memisahkan komponen emosi dan perilaku dari rasa takut, menahan diri untuk tidak memunculkan respons 
Titin Nur Hidayati

melarikan diri. Mereka mampu menghadapi situasi yang kurang nyaman yang ditimbulkan oleh reaksi fisik dan subyektif, mereka juga memiliki keberanian moral dan psikologis. Keberanian moral adalah mengambil sikap yang tidak populer dan bisa jadi merugikan diri sendiri. Keberanian psikologis merupakan ketabahan saat menghadapi kepedihan, mampu memunculkan keceriaan yang diperlukan untuk menghadapi cobaan berat yang serius.

2) Sifat Ulet/Rajin/Tekun

Kekuatan ini ditunjukkan dengan kemampuan dalam menyelesaikan semua yang telah dimulai. Orang yang rajin akan mengerjakan tugas yang sulit dan menyelesaikannya, menuntaskannya dengan riang dan tanpa banyak mengeluh. Selain itu orang yang benarbenar rajin akan bersifat fleksibel, realistis, dan tidak perfeksionis. Ambisi dalam arti positif termasuk dalam kategori kekuatan ini.

3) Integritas/Ketulusan/Kejujuran

Kejujuran merupakan hidup yang dijalani tanpa kepura-puraan dan selalu menjadi orang yang "nyata", bukan sekedar dengan berbicara benar, tetapi juga menjalani hidup yang autentik. Ketulusan dan integritas adalah kemampuan menampilkan diri sendiri (niat dan komitmen) kepada orang lain dan kepada diri sendiri dengan cara-cara yang tulus, melalui perkataan atau perbuatan.

\section{c. Kemanusiaan dan Cinta}

Kekuatan ini diperlihatkan dalam interaksi sosial yang positif dengan orang lain, misalnya teman, kenalan, anggota keluarga, dan juga orang yang masih asing.

46 | Falasifa, Vol. 11 Nomor 1 Maret 2020 
Kebahagiaan Pemimpin Perempuan Dalam Menjalani.....

1) Kebaikan dan Kemurahan Hati

Kebaikan dan kemurahan hati ditandai dengan sikap yang senang berbuat baik untuk orang lain, bahkan kepada orang yang tidak begitu dikenal secara akrab. Semua ciri kategori ini berintikan pengakuan akan berharganya orang lain. Kategori kebaikan hati mencakup beragam cara bergaul dengan orang lain, dengan mengutamakan kepentingannya. Empati dan simpati merupakan komponen yang berguna dalam kekuatan ini.

2) Mencintai dan Bersedia Dicintai

Kekuatan ini ditunjukkan seseorang dengan kemampuan menghargai kedekatan dan keakraban dengan orang lain dengan menunjukkan kecintaan kepada orang lain sepanjang hidup. Jika orang lain juga merasakan penghargaan akan kedekatan dan keakraban tersebut maka seseorang telah terbukti memiliki kekuatan ini.

\section{d. Keadilan}

Kekuatan ini muncul pada aktivitas bermasyarakat. Hal ini mencakup hubungan antarpersonal dan hubungan dalam kelompok yang lebih besar, seperti keluarga, komunitas, bangsa, dan dunia.

1) Bermasyarakat/ Tugas/ Kerja Tim/ Loyalitas

Kekuatan ini ditunjukkan dengan kesediaan untuk berbagi, berdedikasi, bekerja keras, dan menunjukkan sikap hormat dalam kelompok.

2) Keadilan dan Persamaan

Keadilan dan persamaan diterapkan dengan cara memberikan kesempatan kepada setiap orang, memperhatikan kesejahteraan orang lain, meskipun tidak mengenalnya secara Falasifa, Vol. 11 Nomor 1 Maret 2020| 47 
Titin Nur Hidayati

pribadi, kesejahteraan tersebut tetap sama pentingnya dengan kesejahteraan diri sendiri.

3) Kepemimpinan

Pemimpin adalah orang yang handal dalam mengorganisasi kegiatan dan mampu mengawasi jalannya kegiatan tersebut. Pemimpin yang simpatik haruslah seorang pemimpin yang efektif, berusaha agar tugas kelompok dapat terselesaikan, mampu menjaga hubungan yang baik dengan kelompoknya.

\section{e. Kesederhanaan}

Kesederhanaan merujuk pada pengekspresian yang pantas dan moderat dari hasrat dan keinginan seseorang. Orang yang sederhana tidak menekan keinginan, tetapi menunggu kesempatan untuk memenuhinya sehingga tidak merugikan diri sendiri atau orang lain.

1) Pengendalian Diri

Kekuatan ini ditunjukkan dengan kemampuan untuk menahan nafsu, keinginan, dan dorongan pada saat yang tepat. Orang yang memiliki kemampuan mengendalikan diri dengan baik akan mampu mengatur emosinya sendiri saat sesuatu yang buruk sedang terjadi, serta mampu memperbaiki dan menetralkan perasaan negatif.

2) Hati-hati/ Penuh Pertimbangan

Seseorang yang mempertimbangkan sesuatu dengan baik tidak akan mengatakan atau melakukan sesuatu tanpa hati-hati yang kemudian akan disesali. Pribadi yang hati-hati akan memiliki wawasan jauh dan penuh pertimbangan. Ia pandai menahan dorongan hati yang bertujuan jangka pendek demi kesuksesan jangka panjang.

3) Kerendahan Hati dan Kebersahajaan

48 | Falasifa, Vol. 11 Nomor 1 Maret 2020 
Kebahagiaan Pemimpin Perempuan Dalam Menjalani.....

Orang yang rendah hati dan bersahaja lebih suka membiarkan prestasi yang berbicara, tidak menganggap dirinya istimewa, dan orang lain mengakui dan menghargai kebersahajaan tersebut.

\section{f. Transendensi}

Transendensi dalam hal ini dimaksudkan untuk mengartikan kekuatan emosi yang memjangkau ke luar diri untuk menghubungkan seseorang ke suatu yang lebih besar dan lebih permanen (kepada orang lain, masa depan, evolusi, ketuhanan, atau alam semesta).

1) Apresiasi terhadap Keindahan dan Keunggulan

Kekuatan ini muncul ketika seseorang telah mampu menunjukkan penghargaan terhadap keindahan, keunggulan, dan keahlian pada semua bidang dalam kehidupan sehari-hari. Jika kekuatan ini intens muncul maka akan disertai oleh kekaguman dan keingintahuan.

2) Bersyukur

Sebagai sebuah emosi, kekuatan ini berupa ketakjuban, rasa terima kasih, dan apresiasi terhadap hidup. Bersyukur dapat ditujukan kepada manusia maupun untuk sumber impersonal atau nonmanusia (Tuhan, alam, binatang), tetapi tidak dapat ditujukan pada diri sendiri.

3) Harapan/Optimisme/Berpikiran ke Depan

Harapan, optimisme, dan berpikiran ke depan adalah kelompok kekuatan yang mewakili pendirian positif dalam menghadapi masa depan, berharap bahwa peristiwa yang baik akan terjadi, merasakan bahwa hal tersebut akan terwujud apabila diupayakan dengan keras, dan merencanakan kegembiraan pada masa depan sejak saat ini, serta berusaha 
Titin Nur Hidayati

keras dalam hidup untuk mendapatkan tujuan yang diinginkan.

4) Spiritualitas/Tujuan Hidup/Keyakinan/Keagamaan

Kekuatan ini ditunjukkan dengan keyakinan yang kuat dan koheren tentang tujuan dan makna yang lebih tinggi dari alam semesta. Kepercayaan tersebut yang akhirnya membentuk tindakan seseorang dan merupakan sumber kedamaian baginya.

5) Sikap Pemaaf dan Belas Kasih

Kekuatan melalui sikap pemaaf dilakukan seseorang dengan selalu memberikan kesempatan kedua kepada orang lain yang telah berbuat salah kepadanya, yaitu dengan memaafkan dengan prinsip belas kasih. Pemberian maaf menimbulkan sejumlah perubahan bermanfaat pada seseorang yang telah diganggu atau disakiti oleh orang lain, yaitu motivasi dasar atau tendensi tindakannya terhadap orang lain yang telah menyakitinya menjadi lebih positif.

6) Rasa Humor

Kekuatan ini muncul pada orang-orang yang dapat dengan mudah melihat sisi positif kehidupan, mudah tersenyum tertawa, dan membuat orang lain tersenyum.

7) Semangat/Gairah/Antusiasme

Sikap semangat ditunjukkan melalui totalitas seseorang dalam aktivitas yang sedang dijalankan, merasa terinspirasi, bersemangat dalam menjalani hari-hari selanjutnya, dan menularkan gairah tersebut kepada orang lain.

Kekuatan khas dan mendasar yang dimiliki oleh setiap orang akan menumbuhkan kebahagiaan yang autentik jika diterapkan setiap hari dalam bekerja, mencintai, bermain, 
Kebahagiaan Pemimpin Perempuan Dalam Menjalani.....

serta menjadi orang tua. ${ }^{21}$

Penjelasan di atas menunjukkan bahwa kebahagiaan yang dirasakan oleh setiap orang berasal dari berbagai faktor dan bergantung pada kemampuan seseorang dalam menilai kehidupannya secara positif, kepuasan yang dirasakan dalam hidup, serta pemanfaatan kekuatan yang dimiliki dalam segala aktivitasnya. Kebahagiaan tersebut selanjutnya menjadi dasar bagi seseorang untuk menjalani hidup yang lebih baik dan berkualitas.

\section{Ciri-ciri Orang yang Bahagia}

Penelitian yang dilakukan oleh berbagai tokoh yang mengkaji tentang kebahagiaan telah menunjukkan bahwa kebahagiaan memiliki pengaruh besar dalam hidup. Orang yang bahagia pada umumnya memiliki kelebihan di berbagai aspek, diantaranya kecerdasan, pendidikan, penampilan, keterampilan sosial, kinerja yang lebih baik, kontrol diri serta optimisme yang tinggi. ${ }^{22}$

Berdasarkan riset yang dilakukan terhadap orang-orang yang bahagia diperoleh hasil bahwa mereka orang yang bahagia memiliki ciri-ciri sebagai berikut: ${ }^{23}$

a) Memberikan manfaat bagi orang lain (significance). Kehadiran mereka dirasakan sebagai keberuntungan bagi banyak orang tanpa memandang latar belakang orang-orang itu.

b) Menjadi sumber inspirasi bagi orang lain (inspired). Mereka dapat memotivasi orang

${ }^{21}$ Seligman, Martin E.P. Authentic Happiness: Xvi.

${ }^{22}$ Argyle, M. \& Martin, M. The Psychological causes of Happiness. Dalam Strack, F., Argyle, M. \& Schwarz, N. (eds.), Subjective wee-being an Interdisciplinary Perspective (hal. 77-96). (New York, Beijing, Frankfurt, Sao Paulo, Sydney, Tokyo, Toronto: Pergamon Press, 1991), 93.

23 Pasiak, Taufik. (2009). Unlimited Potency of The Brain. Bandung: Mizan. On- line: www.googlebook.com. Akses: 27 Desember 2012.. 175-176.

Falasifa, Vol. 11 Nomor 1 Maret 2020| 51 
Titin Nur Hidayati

lain untuk bergerak melakukan sesuatu dengan tujuan mendapatkan kebahagiaan. Orang yang bahagia dapat menularkan kebahagiaan yang dirasakan kepada orang lain.

c) Memberikan warisan bernilai (legacy). Orang-orang bahagia adalah mereka yang bekerja penuh waktu untuk mewariskan sesuatu yang bernilai dan menghasilkan kebahagiaan. Warisan tersebut dapat berupa ide-ide ilmu pengetahuan, bangunan-bangunan yang bernilai tinggi dan berguna, atau berupa kader-kader yang mengantarkan orang lain pada kehidupan yang lebih baik.

\section{Pengertian Pemimpin Perempuan}

Kepemimpinan adalah proses dimana seorang individu mempengaruhi anggota kelompok lainnya berkaitan dengan pencapaian tujuan kelompok dan tujuan organisasinya. ${ }^{24}$

Kepemimpinan juga diartikan sebagai kemampuan individu untuk mempengaruhi, memotivasi, dan membuat orang lain mampu memberikan kontribusinya demi efektivitas keberhasilan organisasi. $^{25}$

Kepemimpinan tidak dapat dipisahkan dari konsep kekuasaan dan otoritas. Kepemimpinan diartikan sebagai suatu aktivitas untuk mempengaruhi perilaku orang lain agar mereka mau diarahkan untuk mencapai tujuan tertentu. Kekuasaan merupakan suatu potensi pengaruh dari seorang pemimpin, sedangkan otoritas adalah kekuasaan yang disahkan

\footnotetext{
24 Sundari, E. K. Gaya Kepemimpinan Berperspektif Perempuan (Studi Deskriptif Manajemen Kepemimpinan Perempuan dalam OrganisasiSosial). (Laporan penelitian. Women Study Centre Universitas Airlangga, 2006), 7.

25 Astiti, G. R. Pengarub Gaya Kepemimpinan Servant Leadership terhadap Komitmen Bawahan (Follower"s Commitment) yang Berbubungan dengan Atasan di PT. Samudera Shipping Services Devisi Pelayaran Petikemas Cabang Surabaya. (Universitas Airlangga, 2008), 10.

52 | Falasifa, Vol. 11 Nomor 1 Maret 2020
} 
Kebahagiaan Pemimpin Perempuan Dalam Menjalani.....

(legitimazed) oleh suatu peranan formal seorang pemimpin dalam sebuah organisasi. ${ }^{26}$ Definisi tentang kepemimpinan di atas menunjukkan bahwa kehadiran pemimpin tidak dapat dipisahkan dari keberadaan suatu organisasi atau kelompok, karena perannya yang sangat penting dalam mengarahkan bawahannya untuk mencapai tujuan organisasi melalui kepemimpinan yang dijalankannya.

Pemimpin adalah seorang pribadi yang memiliki kecakapan dan kelebihan, khususnya kecakapan-kecakapan di suatu bidang, sehingga dia mampu mempengaruhi orang lain untuk bersama-sama melakukan aktivitas- aktivitas tertentu demi pencapaian satu atau beberapa tujuan. ${ }^{27}$

Pemimpin adalah seseorang yang memimpin, dengan jalan memprakarsai tingkah laku sosial dengan mengatur, menunjukkan, mengorganisir atau mengontrol usaha/upaya orang lain, atau melalui prestise, kekuasaan atau posisi.

Islam memposisikan pemimpin sebagai sosok diperlukan kehadirannya untuk mengarahkan sebuah kelompok. Rasulullah bersabda, "Tika ada dua orang yang berjalan, angkat salah seorang diantara keduanya menjadi imam”. Penegasan Rasulullah tersebut mengindikasikan pentingnya kehadiran pemimpin untuk mengatur dan mengayomi suatu kelompok agar tercipta dan tercapai tujuan bersama secara harmonis. ${ }^{28}$

Kepemimpinan di dalam islam merupakan amanah, tugas, dan tanggung jawab. Apabila unsur tersebut dijalankan dengan baik oleh pemimpin maka akan berpotensi besar mendapatkan perhatian dan apresiasi dari kelompok yang mereka pimpin maupun dari publik.

${ }^{26}$ Faiq, A. Analisis terbadap Kepemimpinan Perempuan dalam Birokrasi Pemerintahan: Studi terhadap Kepemimpinan Perempuan di Kabupaten Tuban Jawa Timur. (Surabaya: Universitas Airlangga, 2005), 12.

${ }^{27}$ Anorogo, P. \& Widiyanti, N. Psikologi dalam Perusahaan. 114.

Falasifa, Vol. 11 Nomor 1 Maret 2020| 53 
Titin Nur Hidayati

Akan tetapi jika jabatan dianggap sebagai kekuasaan, keistimewaan, dan kesewenangwenangan maka akan terjadi kehancuran dan kerusakan antar manusia maupun seluruh yang ada di alam ini. ${ }^{29}$

Berdasarkan definisi yang telah dikemukakan oleh beberapa tokoh di atas maka dapat disimpulkan bahwa pemimpin adalah orang yang dipercaya untuk menjalankan amanah, tugas, dan tanggung jawab dalam mengatur suatu kelompok dan memiliki kemampuan untuk mengarahkan, mengkoordinasikan, dan memotivasi para bawahannya untuk mencapai kinerja yang lebih memuaskan dan mewujudkan tujuan organisasi melalui kepemimpinan yang dijalankannya. Pemimpin yang baik tidak menganggap jabatan yang diterimanya sebagai sebuah kekuasaan, keistimewaan, dan kesewenang-wenangan, sehingga mereka dapat menghargai dan menghormati orang-orang yang mereka pimpin, serta lebih tercipta keharmonisan dalam mencapai tujuan bersama.

\section{Pemimpin Perempuan dalam Tinjauan Psikologi}

Perempuan sebagai pribadi yang lemah lembut, penuh pengertian, bijaksana, dan tekun dalam kepemimpinannya adalah orang yang mempunyai wewenang untuk memerintah orang lain, yang dalam pekerjaannya untuk mencapai tujuan organisasi memerlukan bantuan orang lain. Sebagai seorang pemimpin mereka mempunyai peranan dan senantiasa ikut campur tangan dalam segala masalah yang berkenaan dengan kebutuhan anggota kelompok. $^{30}$

\footnotetext{
${ }^{28}$ Sanusi, A. Jalan Kebahagiaan. (Jakarta: Gema Insani, 2006), 22.

${ }^{29}$ Ibid. 23

${ }^{30}$ Anorogo, P. \& Widiyanti. Psikologi dalam Perusahaan. 45.
} 
Kebahagiaan Pemimpin Perempuan Dalam Menjalani.....

Kepemimpinan perempuan secara normatif memiliki legitimasi yang sangat kuat, baik secara teologis, filosofis, maupun hukum. Deklarasi Universal Hak Asasi Manusia yang telah disetujui oleh negara-negara anggota PBB, termasuk Indonesia, menyebutkan sejumlah pasal yang memberikan kebebasan kepada perempuan untuk memilih pemimpin maupun menjadi pemimpin. Begitu juga dalam konvensi mengenai penghapusan segala bentuk diskriminasi terhadap perempuan yang disahkan melalui Undang-undang Republik Indonesia (UU RI) Nomor 7 Tahun 1984 dan dalam Deklarasi Penghapusan Kekerasan terhadap Perempuan, yang memberikan jaminan bahwa perempuan terbebas dari tindakan diskriminasi dalam bentuk apapun .

Peraturan lain yang mengatur bahwa perempuan memiliki peluang yang sama dengan laki-laki dalam menduduki posisi sebagai pemimpin, diantaranya Undang-undang No. 68 Tahun 1958 tentang Persetujuan Konvensi Hak-hak Politik Kaum Perempuan, Undangundang No. 39 Tahun 1999 tentang Hak Asasi Manusia, yang menjamin keterwakilan perempuan, baik di legislatif, eksekutif, maupun yudikatif, dan Instruksi Presiden No. 9 Tahun 2000 tentang Pengarus Utamaan Gender dalam Pembangunan Nasional, yang mengharuskan seluruh kebijakan dan Program pembangunan Nasional dirancang dengan perspektif gender. ${ }^{31}$

Kesuksesan perempuan dalam mencapai karir sebagai pemimpin di tempat kerja dan menjalankan kepemimpinannya dengan baik menunjukkan bahwa mereka memiliki berbagai kelebihan dalam menjalankan perannya tersebut. Perempuan cenderung mendefinisikan

31 Anshor, M. U. (2009). Tantangan Kepemimpinan Perempuan. Jurnal Studi Gender dan Anak, Volume 3, Edisi I. 1.

Falasifa, Vol. 11 Nomor 1 Maret 2020| 55 
Titin Nur Hidayati

kekuasaan dalam konsep kemampuan untuk merawat atau berkontribusi untuk orang lain. ${ }^{32}$

Rapoport \& Bailyn dalam Sundari juga mengatakan bahwa Pemimpin perempuan tidak hanya menunjukkan keterampilan dalam berpikir linier, asertif, dan kompetitif, tetapi juga keterampilan relasional yang berhubungan dengan dunia privat, wilayah domestik, termasuk membagi informasi, empati, dan sikap memelihara. Keterampilanketerampilan tersebut memberikan kontribusi pada efektivitas dan memfasilitasi penyelesaian pekerjaan. $^{33}$

Sebuah studi tentang kepemimpinan perempuan menyebutkan bahwa perempuan lebih partisipatif dan demokratik dalam gaya kepemimpinannya dibandingkan laki-laki. Pemimpin perempuan lebih cenderung mengembangkan keterampilan interpersonal, lebih interaktif, menekankan pengembangan konsensus, membagi kekuasaan dan informasi melalui kepemimpinannya, serta membantu pemberdayaan karyawan pada semua level. ${ }^{34}$

Beberapa penelitian menunjukkan perbedaan gaya kepemimpinan antara laki-laki dan perempuan, dimana perempuan lebih memperlihatkan gaya transformasional dan lakilaki lebih menunjukkan gaya transaksional. Kepemimpinan transformasional selalu berusaha menciptakan suasana kekeluargaan di dalam dan di antara bawahan/anggota organisasi, dengan saling melindungi dan mendukung proses pengaktualisasian visi yang menguntungkan. ${ }^{35}$

Gaya kepemimpinan transformasional yang lebih ditunjukkan oleh pemimpin

${ }^{32}$ Sundari, E. K. Gaya Kepemimpinan Berperspektif Perempuan. 18.

${ }^{33}$ Ibid, 19

${ }^{34}$ Ibid, 6

${ }^{35}$ Sundari, E. K. Gaya Kepemimpinan Berperspektif Perempuan. 17.

56 | Falasifa, Vol. 11 Nomor 1 Maret 2020 
Kebahagiaan Pemimpin Perempuan Dalam Menjalani.....

perempuan memberikan pengaruh positif bagi dirinya maupun para bawahannya. Pemimpin dengan gaya kepemimpinan transformasional dinilai efektif karena dapat memberikan pengaruh terhadap motivasi para pengikutnya, kemampuannya dalam bekerja, dan kepuasan kerjanya secara keseluruhan. Pengaruh positif yang juga diperoleh melalui kepemimpinan transformasional berkaitan erat dengan komitmen organisasi. Kepemimpinan transformasional merupakan sebuah proses membangun komitmen untuk tujuan organisasi dan pemberdayaan pengikut pada pencapaian keberhasilan. ${ }^{36}$

Berdasarkan penjelasan di atas maka dapat disimpulkan bahwa perempuan memiliki kesempatan yang sama dengan laki-laki untuk menjalankan kepemimpinan di berbagai bidang pekerjaan, bahkan perempuan memiliki kelebihan dalam menjalankan kepemimpinannya. Peluang bagi perempuan untuk menjadi pemimpin di berbagai bidang pekerjaan telah dijamin dan diatur di berbagai undang-undang dan peraturan negara.

Kelebihan para pemimpin perempuan ditunjukkan melalui kepemimpinannya yang cenderung demokratis, lebih menunjukkan sikap empati dan mampu memberikan kontribusi bagi orang lain, serta memiliki keterampilan interpersonal dan relasional yang baik dengan orang lain. Selain itu, pemimpin perempuan memiliki kecenderungan untuk memimpin bawahannya dengan gaya kepemimpinan transformasional, yaitu menekankan pada proses pemberian motivasi kepada bawahan untuk mencapai hasil kerja yang lebih baik, mendahulukan kepentingan kelompok, serta membangun hubungan kekluargaan dalam tim, sehingga mampu meningkatkan kepuasan dalam bekerja dan komitmen organisasi,

36 Kaihatu, T. S. \& Rini, W. A. (2007). Kepemimpinan Transformasional dan Pengaruhnya terhadap Kepuasan atas Kualitas Kehidupan Kerja, Komitmen Organisasi, dan Perilaku Ekstra Peran: Studi Pada Guruguru di Kota Surabaya. Jurnal Manajemen dan Kewirausabaan. Volume 98, No. 1. 55.

Falasifa, Vol. 11 Nomor 1 Maret 2020| 57 
Titin Nur Hidayati

yang berdampak pada pencapaian keberhasilan organisasi.

\section{Peran Ganda Perempuan dalam Tinjauan Psikologi}

Keputusan para perempuan untuk tetap bekerja meskipun telah berkeluarga didasari oleh berbagai faktor. Dua faktor yang paling mendasari keputusan mereka adalah motivasi dan fasilitas yang tersedia. ${ }^{37}$

a) Faktor Motivasi

1. Uang

Uang merupakan salah satu faktor pendorong seorang istri untuk bekerja, karena hal ini didasarkan pada keinginan istri untuk memenuhi kebutuhan, baik kebutuhan rumah tangga maupun kebutuhan diri sendiri.

\section{Peran Sosial}

Selain menjadi ibu tangga, perempuan juga ingin memiliki peran lain di lingkungan sosial, dalam hal ini perannya sebagai pekerja. Mereka ingin memanfaatkan waktu luang yang dimiliki. Waktu luang yang banyak dapat menyebabkan seorang istri menjadi frustrasi karena mereka tidak dapat mengoptimalkan perannya.

3. Kepribadian

Kepribadian yang dimaksud dalam hal ini adalah kepribadian yang berhubungan dengan adanya kebutuhan akan pencapaian (Need of Achievement), kebutuhan akan kekuasaan (Need of Power), dan kebutuhan akan kompetensi diri.

${ }^{37}$ Desmayanti, S. Hubungan Antara Resolusi Konflik dan Kepuasan Pernikahan pada Pasangan Suami Istri Bekerja pada Awal Pernikahan. (Jakarta: Universitas Indonesia, 2009), 18.

58 | Falasifa, Vol. 11 Nomor 1 Maret 2020 
Kebahagiaan Pemimpin Perempuan Dalam Menjalani.....

b) Faktor Fasilitas

1. Faktor situasional yang dipengaruhi oleh seberapa besar peran istri dan ibu yang diperlukan di rumah.

2. Sikap dan nilai dari pasangan maupun lingkungan.

3. Ketersediaan lapangan pekerjaan yang sesuai.

Keputusan perempuan untuk bekerja dan berkarir memberikan pengaruh bagi kepuasan dalam hidupnya. Dengan bekerja, perempuan dapat meningkatkan well being dan kompetensinya, serta dapat meningkatkan kepuasan dalam pernikahan. Konflik dalam rumah tangga dengan istri yang bekerja akan lebih besar, tetapi kebahagiaan yang dirasakan akan lebih tinggi dan keberhasilan untuk mempertahankan pernikahan juga akan lebih tinggi jika dibandingkan dengan istri yang tidak bekerja. ${ }^{38}$

Keputusan perempuan untuk bekerja dan berkarir didasari oleh berbagai faktor yang berasal dari dalam diri maupun luar diri atau lingkungannya. Penjelasan sebelumnya telah menyebutkan bahwa kebahagiaan berasal dari berbagai sumber, salah satunya dari kepuasan kerja. Perempuan yang bekerja diindikasikan memiliki kebahagiaan yang lebih tinggi dibandingkan perempuan yang tidak bekerja, lebih dapat meningkatkan well being dan kompetensinya, serta lebih dapat merasakan kepuasan dalam pernikahan. Berdasarkan hasil penelitian tersebut maka dapat disimpulkan bahwa peran ganda yang dimiliki oleh perempuan memberikan makna dan manfaat tersendiri bagi mereka apabila dapat dijalankan dengan penuh kenyamanan dan seimbang.

\section{Penutup}

\footnotetext{
38 Ibid. 19.
}

Falasifa, Vol. 11 Nomor 1 Maret 2020| 59 
Titin Nur Hidayati

Kelebihan para pemimpin perempuan ditunjukkan melalui kepemimpinannya yang cenderung demokratis, lebih menunjukkan sikap empati dan mampu memberikan kontribusi bagi orang lain, serta memiliki keterampilan interpersonal dan relasional yang baik dengan orang lain. Selain itu, pemimpin perempuan memiliki kecenderungan untuk memimpin bawahannya dengan gaya kepemimpinan transformasional, yaitu menekankan pada proses pemberian motivasi kepada bawahan untuk mencapai hasil kerja yang lebih baik, mendahulukan kepentingan kelompok, serta membangun hubungan kekluargaan dalam tim, sehingga mampu meningkatkan kepuasan dalam bekerja dan komitmen organisasi, yang berdampak pada pencapaian keberhasilan organisasi

\section{DAFTAR PUSTAKA}

Anorogo, P. \& Widiyanti, N. 1993. Psikologi dalam Perusahaan. Jakarta: PT. Rineka Cipta.

Anshor, M. U. 2009. Tantangan Kepemimpinan Perempuan. Jurnal Studi Gender dan Anak, Volume 3, Edisi I.

Argyle, M. \& Martin, M. 1991. The Psychological causes of Happiness. Dalam Strack, F., Argyle, M. \& Schwarz, N. (eds.), Subjective wee-being an Interdisciplinary Perspective (hal. 77-96). New York, Beijing, Frankfurt, Sao Paulo, Sydney, Tokyo, Toronto: Pergamon Press.

Astiti, G. R. 2008. Pengarub Gaya Kepemimpinan Servant Leadership terhadap Komitmen Bawahan (Follower"s Commitment) yang Berbubungan dengan Atasan di PT. Samudera Shipping Services Devisi Pelayaran Petikemas Cabang Surabaya. Surabaya: Universitas Airlangga.

Astuti, D. T. 2007. Hubungan Antara Tingkat Kebahagiaan Autentike (Authentic Happiness) dengan Tingkat Perilaku Inovasi Pada Wirausahawan Distro Di Surabaya, Sidoarjo, dan Malang. Surabaya: Universitas Airlangga.

Desmayanti, S. 2009. Hubungan Antara Resolusi Konflik dan Kepuasan Pernikahan pada Pasangan Suami Istri Bekerja pada Awal Pernikahan. Skripsi. Fakultas Psikologi. Jakarta: Universitas Indonesia.

Diener, E. \& Kesebir, P. 2008. In Pursuit of Happiness: Empirical Answers to Philosophical 60 | Falasifa, Vol. 11 Nomor 1 Maret 2020 
Kebahagiaan Pemimpin Perempuan Dalam Menjalani.....

Questions. Volume 3 No. 2, 117-125.

Faiq, A. 2005. Analisis terbadap Kepemimpinan Perempuan dalam Birokrasi Pemerintahan: Studi terbadap Kepemimpinan Perempuan di Kabupaten Tuban Jawa Timur. Tesis. Pasca Sarjana Pengembangan Sumber Daya Manusia. Surabaya: Universitas Airlangga.

Kaihatu, T. S. \& Rini, W. A. 2007. Kepemimpinan Transformasional dan Pengaruhnya terhadap Kepuasan atas Kualitas Kehidupan Kerja, Komitmen Organisasi, dan Perilaku Ekstra Peran: Studi Pada Guru-guru di Kota Surabaya. Jurnal Manajemen dan Kewirausahaan. Volume 98, No. 1. 49-61.

Khavari, K. A. 2006. The Art of Happiness: Mencipta Kebahagiaan dalam Setiap Keadaan. Jakarta: PT. Serambi Ilmu Semesta.

Larsen, J. T. \& McKibban, A. R. 2008. Is Happiness Having What You Want, Wanting What You Have, or Both?. Volume. 19, No. 4, 371-377.

Oriza, I. D. I. 2009. Hubungan antara Kekuatan Karakter dan Kebahagiaan Pada Suku Bugis. C-S Bugis Jurnal. 1-18.

Pasiak, Taufik. 2009. Unlimited Potency of The Brain. Bandung: Mizan. On- line: www.googlebook.com. Akses: 27 Desember 2012.

Sanusi, A. 2006. Jalan Kebahagiaan. Jakarta: Gema Insani.

Seligman, Martin E.P. 2005. Authentic Happiness: Menciptakan Kebahagiaan dengan Psikologi Positif. Bandung: Mizan.

Sundari, E. K. 2006. Gaya Kepemimpinan Berperspektif Perempuan (Studi Deskriptif Manajemen Kepemimpinan Perempuan dalam Organisasi Sosial). Laporan penelitian. Women Study Centre Universitas Airlangga.

Falasifa, Vol. 11 Nomor 1 Maret 2020| 61 